UDC 94(479.22)“1920"

DOI 10.24919/2519-058X.20.240035

\begin{abstract}
Arthur MARGULOV
PhD hab. (History), Professor of the department of Social Sciences and Humanities, Dnipropetrovsk State University of Internal Affairs, 26 Gagarin Avenue, Dnipro, Ukraine, postal code 49107 (margulov@gmail.com)
\end{abstract}

ORCID: 0000-0001-9543-540x

\title{
Артур МАРГУЛОВ
}

доктор історичних наук, професор кафедри соиіально-гуманітарних дисциплін Дніпропетровського університету внутрішніх справ, проспект Гагаріна, 26, м. Дніпро, Україна, індекс 49107 (margulov@gmail.com)

Bibliographic Description of the Article: Margulov, A. (2021). Assyrian National Elites of Georgia in the 1920s: Public Policy and National Cultural Identity. Skhidnoievropeiskyi Istorychnyi Visnyk [East European Historical Bulletin], 20, 93-103. doi: 10.24919/2519-058X.20.240035

\section{ASSYRIAN NATIONAL ELITES OF GEORGIA IN THE 1920s: PUBLIC POLICY AND NATIONAL CULTURAL IDENTITY}

\begin{abstract}
The purpose of the article is to explore the paradigm of the relationship between a national minority and a state in which an authoritarian and totalitarian model of government is formed. This analysis is conducted by the author on the relationship between the state and a national elite. The research methods: realization of the specified purpose demands from the researcher use of historical-system, historical and biographical, comparative methods, the complex approach. Main results, brief conclusions: At the beginning of the 20th century, Georgia became a center not only for the emigrant and refugee masses of the Assyrians, but also for the national and political elite. The years of Georgian state-building coincided with an active stage in the implementation of the Assyrian national issue in the field of international law. The Soviet government radically changed the methodology for resolving the Assyrian national issue. Markers of a national statehood were replaced by the Soviet loyalty artificially. Elites who became the generator of solutions to the national issues were repressed and replaced by loyalists to the existing system. The issue of obtaining various formats of statehood had long been removed from the agenda. The practical significance: the results of the study can be used for further scientific research on the history of the Soviet totalitarianism and the history of the Assyrians in the USSR in the 1920s and 1930s. The scientific novelty: the research is formed on the basis of a wide range of historical sources. The author presents the material stored in the archives of the Ministry of Internal Affairs of Georgia, the Central Historical Archive of the National Archives of Georgia, the State Archives of the Russian Federation, the Russian State Archives of Socio-Political History, the State Institution "National Archives of the Republic of Adygea". Article type: analytical.
\end{abstract}

Key words: Soviet totalitarianism, Assyrian national minority, Public policy, National elites.

\section{АССИРІЙСЬКІ НАЦІОНАЛЬНІ ЕЛІТИ ГРУЗІЇ У 1920-х рр.: ДЕРЖАВНА ПОЛІТИКА ТА НАЦІОНАЛЬНО-КУЛЬТУРНА ІДЕНТИЧНІСТЬ}

Анотація. Мета статmі - полягає у тому, щзоб дослідити парадигму взаємовідносин між національною меншиною та державою, в якій формується авторитарно-тоталітарна модель управління. Даний аналіз автор проводить на взаємовідносин держава-національна 
еліта. Методи дослідження: реалізація зазначеної мети вимагає від дослідника використання історико-системного, історико-біографічного та компаратівного методів, комплексного підходу. Основні результати, стислі висновки: Грузія початок XX століття стає центром не тільки для емігрантсько-біженських мас ассирійців, а й для національно-політичної еліти. Роки грузинського державного будівництва збіглися з активним етапом реалізачії ассирійського національного питання в полі міжнародного права. Радянська влада кардинально змінюе методологію рімення ассирійського національного питання. Маркери національної державності штучно змінюються на радянську лояльність. Еліти, які стали генератором рімень національних питань були репресовані і замінені лояльними до існуючого ладу. Питання про отримання різних форматів державності надовго було знято з порядку денного. Практичне значення: результати дослідження можна використовувати для подальших наукових пошуків історії радянського тоталітаризму та історії ассирійців на території СРСР у 1920-1930-х рр. Оригінальність: поєднання дослідження функиіонування національної еліти та майбутнього існування наиіональноїгромади в умовах формування тоталітарноїмоделі управління державою. Наукова новизна: дослідження формується на підгрунті широкого кола історичних джерел. Автор презентує матеріал, який зберігається у фондах Архіву Міністерства внутрішніх справ Грузії, Центрального історичного архіву Національного архіву Грузії, Державного архіву Російської Федерачії, Російського державного архіву сочіально-політичної історії, Державного закладу «Національний Архів Республіки Адигеї». Тип статті: аналітична.

Ключові слова: радянський тоталітаризм, ассирійська начіональна меншина, етнічні еліти.

The Problem Statement. The wave of national liberation movements, which flooded the European political space in the XIXth - at the beginning of the XXth century found its echoes everywhere in the world. This became possible because of transformation processes of the systems of colonial and imperial ownership, the transition to the industrial phase of society, the growth of the number of political parties and their active participation in the life of the states. Under these conditions, the historical claims of nations that did not have or lost their own statehood to self-determination were realized and came true.

The Assyrians, who traditionally lived in Turkey and Persia, due to historical circumstances, were drawn into these processes. Their desire for their own statehood was caused by the searches for safe models of existence in a non-national and mono-confessional hostile environment. Over the centuries, the uncertain opportunity to achieve this goal used to appear. The issue of the return of statehood and the restoration of historical justice arose very acutely during World War I and especially acutely after its end. Supporting the Entente countries the Assyrians hoped to resolve their statehood issue. The territorial sovereignty of the Assyrians was one of the issues, which were discussed at the Lausanne Conference (November 20,1922) and later at the Council of the League (1925) (Matveyev, 1979, pp. 95-106).

The Assyrian elite were inspired by the ideas of the state sovereignty and establishment of statehood. These ideas found a response among a few ranks of the Assyrian elite. And for many decades it was declared as the main task of their consolidated work. The territory of the Russian Empire, in particular Georgia, becomes the generating centers for such ideas (Komakhia, 2006, pp. 159-164).

The scientific interest of specialists, who were involved in the survey of the USSR's history is aimed at the issue of the national policy during the period of a totalitarian system formation. These debates were resulted in radically opposite judgments using the appropriate evidence base that is opened up to modern researchers nowadays.

Representatives of the theory of the ethnization of Stalinism present the concept of the directed repressive policy of the Soviet state concerning the national minorities living at its territory (Mick, 2006, pp. 145-147; Baberowski, 2003, pp. 195-196). According to this 
concept national minorities and titular republican nations are considered as a "competitor" in information and ideological space formation for the approval of the Soviet state ideology.

Their opponents were researchers who supported and adhered to the concept of Harvard University professor Terry Martin. In his research, he presents the USSR as the empire of "a positive activity". In these works the emphases are aimed at meeting the needs of the national outskirts and national minorities in a greater part than the Russians (Martin, 2015).

Analyzing the state national policy, we move to the republican level. This level can give researchers a complete picture of the specifics of the Soviet national policy. In his works, Stanislav Kulchytskyy, the Ukrainian researcher (Kulchytskyy, 2014) refutes the concept of Terry Martin, arguing that the republican titular nations have no independence from Moscow center, as well as he rejects the pursuit of a massive, repressive policy.

Continuing to adhere to the republican format, we can observe the continuation of the allunion discussion. We witnessed a scientific dispute about the role of the republican titular nation in the regulation of a national policy concerning the national minorities at the territory of Georgia during the interwar period. Researchers and public figures from Georgia, Germany and foreigners who live in Georgia took part in the discussion. The subject of a lively dispute was the question of the role of the republican party and Soviet bodies in carrying out actions of the Great Terror against the backdrop of the all-Soviet repressive campaign. As well as making the boundary of responsibility delimitation of the center and the republic (Junge \& Bonwerch, 2015).

In their work, the French researchers Joseph and Claire Yacoub present the history of the Assyrians of the Caucasus during the Soviet period (1920 - 1991) as a positive trend, focusing on several stages of cultural and social upsurge (Yacoub, 2015). The works of Hegumen Stefan (Sado) and Sergei Osipov are noteworthy (Hegumen Stefan (Sado), 2017; Osipov, 2007) These works represent a wide range of factual, both bibliographic and historical material. The authors of classic works on the history of the Assyrians who lived at the territory of the USSR are A. K. Matveev and K. P. Matveev. Working in the chronological framework of the Soviet period, they were able to identify the main historical and ethnographic markers of the existence of the Assyrians at the territory of the USSR. Unfortunately, in our opinion, we are not able to reproduce fully the chronology and essence of events from the history of the Assyrians of Georgia in the 1920s - 1930s based on these works.

The analysis of the scientific literature allows us to conclude that the problems we have chosen have not become the subject of research both by the international scientific community and the domestic (Georgian) one. In the works of the Georgian researchers, the main place is given to more numerous nationalities and promising directions of thestate policy (Tsarakhov, 2004; Natmeladze \& Daushvyly, 2008; Daushvyly \& Natmeladze, 2011).

The Analysisof Sources and Recent Researches. Representatives of the theory of the ethnization of Stalinism present the concept of a directed repressive policy of the Soviet state in relation to national minorities living at its territory (Baberowski, 2003, pp. 195-196; Jones, 1988). National minorities and titular republican nations are considered in this concept as a "competitor" in the process of creating an informational and ideological space for the establishment of Soviet state ideology.

Their opponents were researchers who adhered to the concept of Professor Terry Martin, University of Harvard. In his studies, he presents the USSR as the empire of "a positive activity". These works emphasize the satisfaction of the needs of national suburbs and national minorities in the greater part than the Russian population (Terry, 2011). 
When analyzing the state national policy, we are moving to research the situation onto the republican level. This part of knowledge may give researchers a complete picture of the specifics of the Soviet national politics (Kul'chitskiy, 2014). In his works, the Ukrainian researcher Stanislav Kulchitsky disproves the concept of Terry Martin, arguing that the republican titular nations lack independence from Moscow center, as well as pointing the mass phased repressive policy is conducted.

Continuing to adhere to the republican format, we can see the continuation of the allUnion discussion. Thus, we witnessed a scientific debate about the role of the republican titular nation in the regulation of national policies in relation to the national minorities in Georgia during the interwar period (Junge, Bonwerch, 2015).

In their work, the French researchers Joseph and Claire Yacoub present the history of the Assyrians of the Caucasus of the Soviet period (1920 - 1991) as a positive trend. They focused their attention on several stages of cultural and social upsurge (Yacoub, 2015). The works of Father Superior Stefan (Sado) and Sergei Osipov are worth analyzing (Hegumen Stefan (Sado), 2017; Osipov, 2007). These works represent a wide range of factual, bibliographic, and historical material. The authors of the classic works on the history of the Assyrians who lived in the USSR were A. K. Matveev and K. P. Matveev (Matveev, 1990; Matveev, 1968; Matveev, 1979). Unfortunately, in our opinion, we are unable to rely on the indicated works to fully reconstruct the chronology and essence of events from the history of the Assyrians of Georgia in the 1920s and 1930s.

The Main Material Statement. Considering the Assyrians living in Georgia in the 1920s - 1930s the object of the state policy, we managed to introduce into the scientific circulation a number of archival materials that made it possible to draw independent conclusions.

Meanwhile, it must be noted that the history of the Assyrian minority at the territory of Georgia cannot have a centric sequence, but it is closely connected and involved into the national policy of the state-republican level.

The analysis of the socio-economic development of the Assyrian community leads us to the conclusion of its pre-industrial state, which automatically affects the qualitative and quantitative indicators of the national elite. The classification of the Assyrian elite at the beginning of the century has some ethno-national characteristics. We tend to rank among the traditional elite who have influence over the community, the clergy (especially Mar-Shumun (a religious and secular head of the Assyrians)), Malik (tribal princes and members of their families). By the end of the XIXth century functional elites appear in the society. They are public leaders, representatives of the intelligentsia (teachers, doctors), officers of the tsarist army and national Assyrian battalions. To the elite of the period of the end of the XIXth-the beginning of the XXth century one can also add people with higher or at least secondary education. It can be proved on the results of their active social mobility and the orientation of society towards their achievement.

At the beginning of the 20th century Georgia had the status of the unofficial national center of the Assyrian refugees. It was the county, which, in our opinion, was one of those territories where the mass settlement of the Assyrians acquired political and legal forms. This was facilitated by a number of factors, such as traditionalism in resettlement, the high economic level of development of representatives of the local Assyrian community, the availability of vacancies for employment and a competitive labour market, a positive educational marker, the concentration of politically active refugees. 
As the confirmation of our argument we can use the following document. In September of 1917, the Special Transcaucasian Committee (OZAKOM) considered the issue of the uncontrolled and unauthorized resettlement of the Persian and Persian-Assyrian citizens from Persia. The immigrants had refugee certificates, which were issued in great numbers by the Assyrian priests in Julfa - Lazarus Georges and in Tiflis - Abbot of the Church of St. Efrem Sirin - A. Beat-Alkhas. The resolution had a decision to suppress unauthorized movement, which complicates "local life" and does not contribute to the matter of counting the population; it confirmed that the movement of refugees within the Caucasus is allowed and is known by the Executive Committee of the Council on the organization of refugees of the Caucasian front. The resolution forbade the issuance of refugee certificates by the Assyrian priests. The decision was made in response to the appeal of the Council's Executive Committee on the refugee system of the Caucasian Front (CHA of Georgia, f. 1950, d. 1, c. 77, p. 237). We also know that in the Russian consulate in Julfa there was information that a person named Mirza Venyamin, a Syrian from Khosrov, helped the Turkish citizens to get Persian passports for 4-8 cranes for a further movement to Tiflis (1916) (CHA of Georgia, f. 520, d. 1, c. 2, p. 4). Because of a lot of refugees, and the government's inability of their support, the Tiflis Governor received the order from Major-General Tamashev (05/24/16). It was prescribed to send refugees from Tiflis: 2193 people were to be sent to Erivan province, 4000 people to Nakhichevan, 500 people to Julfa (CHA of Georgia, f. 520, d. 1, c. 33, p. 145).

From the report to the commander-in-chief on the organization of refugees of the Caucasian Front made by A. Shelkovnikov, where we can see the following facts: the Assyrians have got the idea of the geographical and political unification of their people. A. Shelkovnikov interviewed representatives of the Assyrian people in the city of Khoi, the Bishop MarElijah and the Dr. F. Beat-Abramov. There is another document with similar specifics, it is a report of the Commander-in-Chief on the organization of refugees of the Caucasian Front, made by Major General Tomashev from Nikitin July 9, 1916: there are 10 thousand Turkish refugees in Persia, they should be supported because of: 1 . The traditional policy towards the Christians East; 2. it is necessary to "strengthen gratitude to Russia in the minds of this nation". It is also noted that 10 thousand Turkish Christians do nothing because of their lack of culture. They settled on clan-tribal basis (CHA of Georgia, f. 520, d. 1, c. 4, p. 172). As we see, the need for humanitarian support for the Assyrians coincided with need of the state policy of the Russian Empire.

Among the majority of the Assyrian population, the mood to return to their homeland was widespread, which was especially characteristic in the 1920s (NA of the Republic of Adygea, f. 136 , d. 1, c. 8 , p. 163). This is supported by documented facts: the activities of a unity of political party of the Assyrians of that period have got the goal to return to their homeland (RGASPI, f. 495, d. 1, c. 51, p. 127).

When using the concept of the Czech researcher M. Grokh on the formation of nations and national movements of small nations, we can state that the Assyrians were at the beginning of the third stage at the beginning of the 20th century. The first stage, connected with the appearance of scientific works on the history and culture of the Assyrians, was inspired from the middle of the XIXth century by missionaries in Persia and Turkey (places of traditionallycompact residence).

With the active participation of American and English missionaries, the written literary language of modern Assyrians was created in the 40s of the XIXth century, it replaced the Old Syriac language that was far from the spoken language of the overwhelming majority 
of the population. This practice was closely connected with the legacy of the Old Syriac language. The main drawback of the ancient language was that even under the conditions of its secular functioning it did not receive literary development and existed in the oral tradition of the people (Lalayan, 1914, p. 6).

With the organization of the Urmia Orthodox mission (the Russian Orthodox Church) at the territory of Persia, there was an urgent need for a comprehensive study of the new congregation, which would probably speed up the missionary process.

During this period, the foundations of the second stage were laid. It was the birth of nationally conscious elite who had the desire to establish national statehood. Enlisting all the possibilities, the national elite sought to raise the self-consciousness of the masses to the level of the nationalist movement.

While the Assyrians were at the territory of the Russian Empire, the case of the existence of a national party was recorded; it was the Assyrian Socialist Party. The history of this party dates back to January of 1916. This Party was founded by the patriotic intelligentsia in the city of Urmia in North-West Persia. At the stage of party organization, its central committee was headed by Benjamin Arsanis (a graduate of the Lazarev Institute of Oriental Languages). By 1917, the party had its own cells in the villages of Urmii district and Salmas, in the Transcaucasus (in the cities of Tiflis and Yerivan) and had more than two hundred full members. The establishing activities involved also the measures to unite scattered Assyrian communities at the historical territory and gain a certain level of independence. Based on this, the cells in the Russian Empire and, subsequently, the Soviet Union were supposed to facilitate the return of the Assyrians to their homeland (RGASPI. f. 495. d. 1. c. 51, pp. 131-133).

Such a nationally-oriented process did not suit the Bolsheviks because the role and place of the Soviet party and the government were completely leveled. Other priorities were presented that were radically opposed to the tasks of building the Soviet society on the principles of communism.

Stalin in his work "Marxism and the National Issue" defines the main directions of the party in the national issue. He characterizes the nation as a community of language, culture, history and territory (Stalin, 1946, p. 269). When interpreting the multi-ethnicity of the Soviet Union exclusively in the key of Sovietization, the authorities made an attempt to erode the national markers in stages. The nation was perceived as a politico-social community, that is why, the Soviet functionaries tried to monopolize all the intra-national processes. One of the obstacles in this area, under the conditions of "political pluralism" of the beginning of the1920s, could be the national elites.

Representatives of the traditional elite became an "alien element" in the Soviet realities, it was they who were regarded by the authorities as a vestige of the old order. Such a position of the state towards representatives of traditional elites in combination with targeted measures completely discredited them in the eyes of the community and reduced their managerial and authority functions to zero. Our attention will be focused on the socio-political elite who took the responsibility to transfer the Assyrian national issue to a new plane in the international arena. It was a small group of people who stood at the forefront of modernity, but without losing their own national identity. It should be noted that, institutionally, this type of elite had no historical tradition in the national environment. Its appearance was a consequence of the educational and cultural mobility of certain representatives of the Assyrian community. This fact influenced the level of authority and support from the general public.

On January 3, 1918, the National Council of Transcaucasia was elected out of 17 members and 6 commissioners delegated to the localities by a national convention of the Assyrians 
residing at the territory of the Transcaucasus. The initiative to convene a congress proceeded from F. Beat-Abram (he was elected a chairman), and he operated on the powers that were granted to him by Mar-Simun. During the voting, V. Eyvazov (he was elected an assistant chairman) insisted that the Assyrian who has the Transcaucasian origin should be the chairman of the Council (MIA archive, f. 6, c. 6, p. 17). Initially, the work of the council consisted in arranging the Assyrian refugees from Persia, Turkey, from Erivan and Kars provinces.

In January of 1918, the decree named "On the new conditions of service on the Caucasian front ..."was issued, where the army command announced the appearance of national combat units consisted of the Armenians, the Georgians, the Ukrainians, the Muslims, the Greeks, the Assyrians, the Ossetians, the Russians people (CHA of Georgia, f. 1968, d. 1, c. 22, p. 22). On January 16, 1918, permission to form the Assyrian battalion in the city of Erivan was received from the front headquarters, the supply of which was taken over by the front headquarters (CHA of Georgia, f. 1968, d. 1, c. 32, p. 5).

Representatives of the Council joined this process immediately. In February of 1918, F. Beat-Abram, a Chairman of the Assyrian National Council of the Transcaucasus, corresponded with the Inter-Ethnic Military Council at the Naval Commissar of the Transcaucasian Commissariat on the issues of form and insignia for officers of the Assyrian units (CHA of Georgia, f. 1968, d. 1, c. 32, p. 2). The Chairman of the Assyrian National Council not only dealt with these issues, but he was always up to date on the events on the Persian front, informing all sorts of instances about the events.

The data show that the Council initially went out of its sphere of competence; it was in constant informative area about the events on the Caucasian front. The possibility of the formation of the national military formations as an army basis for the future state formation was considered.

The Council worked for five months under the leadership of Dr. F. Beat-Abram as a Chairman. But in the spring, many members of the Council disagreed, and in May of 1918 only 3 active members remained. At the last meeting on May 22 it was decided to dissolve the Council. The reasons for such actions were the following: differences of opinion on various issues among the Assyrians of Persians, Turkey and Transcaucasia on the issue of the elimination of military units in Tiflis, company and battalion in Erivan, which were created to protect the left flank of the Caucasian front after peace and the closure of the Erivan-Julfa road; 3 members representing a minority could not be considered as legal body (CHA of Georgia, f. 520, d. 1, c. 240, p. 3).

A. Badalov, in his duty of being a chairman of the Transcaucasian National Council, went to Denikin's bid (October 21, 1919) to resolve the issue of granting the Assyrians temporary accommodation in response to the demands of the Georgian national government to evict the Assyrians.

At the meeting, they expressed their solidarity with the actions of the Volunteer Army, and the readiness to provide assistance from the Assyrians of the Transcaucasus. Such actions were condemned by the other wing of the Assyrian People's Council (F. Beat-Abram) in the newspaper "Great Russia" No. 305 (Rostov edition) of October 8, 1919.

The Assyrians had a split - some were guided by the national Georgian government and chose a new national Assyrian Council in Georgia, the others held the former Assyrian Council of Transcaucasia (MIA archive, f. 6, c. 2341, p. 28). There were two identical organizations that did not recognize the activities of one another. And it was a natural process, the symptoms of which were diagnosed at the constituent assembly. The difference of goals 
and the conflict of interests of local and the Assyrian refugees on the other hand were the dynamics of political changes within Georgia and the region itself.

At a meeting of the Assyrian deputies in Georgia, the Assyrian National Council in Georgia decided to close that official body and organize the new Assyrian National Council of Georgia (ASSNARS). On March 6, 1921 at the secondary meeting of the Assyrian deputies of Georgia they elected the executive committee of the Assyrian People's Council after the meeting on March 11 in the building of the 105 Assyrian labour school on a Brick lane (MIA archive, f. 6, c. 22110, pp. 210-212). Beat-Abram F. Ya. became the chairman, Oganezov Babe and Beat Eyvaz were elected the Comrades of a Chairman, Beat Ward V., Beat Baba M. was a Secretary, Beat Urmuz A., Beat Tuma T. - was a Treasurer, Beat Peer M., Beat-Dances R. were the members of the executive committee. (March 23, 1921. F. Makharadze approved the charter) (MIA archive. f. 6. d. 22110, p. 131). Shumun Gandzha was the President at the congress; (later he immigrated to America), Beat-Babkash A. was a secretary; (later he was repressed on 03.10.1938) (MIA archive, f. 12. Lists of those shot in 1937 - 1938, p. 13).

Assyrian People's Council under Soviet Georgia on April 20, 1922, Tiflis sent an analytical note to the Supreme Court. It ran that the Assyrians in Georgia are made up of citizens of Georgia and of refugees from North-West Persia, and Turkey (1915 - 1918). The citizens of Georgia inhabited almost 100\% purely Assyrian villages (Dzveli Kanda and Mirzoevka); among the semi-Assyrian village there was Vasilyevka, there were about 1000 people. They are engaged in arable farming. Among foreign nationals there was the craft proletariat who, before the war, came to Tiflis at the end of the XIXth - beginning of the XXth centuries. The best stone official buildings and private houses were built by the Assyrian masons, carpenters, and painters. There were about 3.5 thousand such emigrants with family members. There were about 1200 people of the highlanders of the Assyrians; they were former Turkish citizens in the cities of Batum, Kutais. There were also 200 people of petty bourgeois, intellectuals, homeowners, contractors, breeders. Total number was not more than 6 thousand people (MIA archive, f. 6, c. 22110, p. 207).

The sympathies of the Persian and Turkish-granted Assyrian elite in relations with Russia passed on, in our opinion, evolution, but they were constantly considered in the context of own national state-building. To confirm this thesis, we present some facts from the public political life of the Assyrians.

They were in relations with Russia as a political entity without attachment to a political regime and a method of organization. In Persia in April of 1917, the document "The Urmian manifesto of the association for Free Assyria" was signed. It consisted of 20 articles, the purpose of which was to establish national government with future accession to Russia with autonomy at the territories compactly populated by the Assyrians (in the region of Urmia, Mosul, Julamerka and others). The Assyrian National Council met the news of the victory of the revolution by holding a support meeting of many thousands, at which B. Arsanis, BeatAbram Freydun, Mar-Shimun had speeches (Sargizov, 1979, p. 69).

Another significant event was the writing of a memorandum by representatives of the National Council of the Transcaucasus dated on December 20, 1918. Its signatories were F. Beat-Abram, Veniaminov, Teimurazov. This memorandum was sent to the commander of British troops in Baku, Major General Thomson, the British, French, American Consuls representative of the Russian government, the Transcaucasian Russian National Council. After the historical preamble, this document dealt with the provision of weapons to the Assyrian fighting forces, the reunification of all lands with compact residence in a united 
state, with further international patronage, payment of reparations to the Assyrian state by Persia and Turkey (CHA of Georgia, f. 1820, d. 150. c. 42, p. 10).

The first congress of the Assyrians of the Soviet Union, held in Moscow in 1925, demonstrated the hierarchy of the Assyrian ethno-territorial communities at the territory of the Soviet Union. The RSFSR was to be represented by 12 delegates from seven cities (Moscow - 4, Leningrad - 2, Rostov-on-Don - 2, Armavir - 1, Art. Labinsk - 1, Voronezh - 1, Vladimir - 1), from the Georgian SSR - seven delegates, from the Armenian SSR - four people, the Azerbaijan SSR - two people, the Ukrainian SSR - six representatives (Kyiv-2, Kharkiv-1, Slovyansk - 1, Stalino - 1, Yekaterinoslav-1) (GARF, f. 3302, d. 1, c. 14, p. 7). As it canbe seen, the Assyrian community of Georgia was the most numerous among other regions of the Soviet Union. This may be another proof of its quantitative composition and advanced socio-political positions held by its representatives at the territory of the Soviet Union.

It is believed that the peak of the repressive policy of the Soviet government dates back to the years of $1937-1938$. This is indicated by direct facts as a legislative rationale, trained personnel, the number of victims, an elaborated procedural mechanism, and socioeconomic and political consequences. In this material we wanted to change the vector of the research for the period of the 1920s, the time when the Soviet authorities were not yet so authoritative in the society, but they already demonstrated the tectonics of the future state system in the public law area.

Without a more effective tool for reformatting national elites, the Soviet authorities used repression as an effective argument. An exceptional majority of members of the functional Assyrian elite were persecuted with varying degrees of intensity and consequences. Alexander Badalov was arrested in December of 1921 on charges of fraud and counter-revolutionary activities. The protocol of the meeting of the Collegium of the Cheka of Georgia from June 25-27, 1922 A. Badalov was sentenced to 3 years of camps with confiscation of property (MIA archive, f. 6, c. 22110, pp. 191, 232).

In the activities of Freydun Yakovlevich, espionage was discerned, his case as a person accused was transferred to the people's commissariat of justice the SSR of Georgia for a public hearing, and as the result of October 2, 1926 he was shot (MIA archive, f. 12. Lists of those shot in 1937 - 1938, p. 18).

Accused cases against social activists were not a single phenomenon in the 1920s. In October of 1926, Vladimir Pavlovich Eyvazov (b. 1885) was arrested. By the decision of the Special Meeting at the OGPU College on February 11, 1927 V. Eyvazov was sentenced to 3 years in the camps. A year earlier (October of1925), Ivan Oganezov (born in 1885) was arrested; from 1921 a member of the RCP (b), although a poorly literate painter. He was a deputy chairman of the Assyrian National Council. The set of charges against him led to the application of capital punishment (01.25.26).

The Conclusions. Active citizenship with a clear national color led to sad consequences. Regarding such actions as an open threat, the Soviet government, long before the start of the Great Terror, began to "clean out" the initiative public space. The victims of such policy were representatives of the national elite. The first wave of repression broke out at the beginning of the 1920s for the representative of the Assyrian community. Punishments, in our opinion, also had a conditional differentiation; the leaders of the Assyrian movement, who were of a Russian origin, were sentenced to shorter terms.

As we see, among the Assyrian social and political elite of the beginning ofthe1920s there was a conflict situation. The society was divided into two polar centers: the local population 
followed the pro-Russian policy (fully adapted to the local conditions of life), the refugees from Persia and Turkey were considering options for returning to their historic homeland in the format of an independent state association. Such trends led to an open form of conflict that entered the public area through the media.

Each of the parties was forced to interact with the existing government of the time, despite the presentation of its emphasized neutrality. Taking a clearly expressed pro-national position, and demonstrating the desire to defend the interests of the national community, the elite presented themselves. And at the same time, it became a victim of political repression by the Soviet government bodies. Selective repressions against the Assyrian national elite were able to reverse the vector of geopolitical orientation. In some period of time, the idea of a national state foundation disappeared from the information space. The elite, who were Persian or Turkish in origin and held an active civil position in Georgia before and during the initial Soviet period, were completely removed from the administrative resource. Tools of such work were repression by the state or emigration. Despite their selectivity and the nonmass nature of the repression during the 1920 s, they were able to reorient the Assyrians to the concepts of the Soviet state-building.

Analyzing the debate about the role of the Soviet state national policy, we can see distinctive imbalance clearly. On the one hand, the state, through its legislative acts, announced the policy of "indigenousization", but on the other hand, it repressed the entire elite that could put national authenticity into this policy and could give a fresh breath into national idea. "Cultural revolutions" had objectives that corresponded to the interests of government to build the Soviet statehood which destroyed a national identity. In this issue the basic concepts of the theory of "ethnization" of Leninist-Stalinist politics concerning the Assyrians who lived in Georgia are manifested.

Acknowledgments. We express sincere gratitude to all members of the editorial board for consultations provided during the preparation of the article for printing.

Funding. The author received no financial support for the research, authorship, and/or publication of this article.

\section{BIBLIOGRAPHY}

Arkhiv Mynysterstva vnutrennikh del Gruzii [MIA archive - Archive of the Ministry of Internal Affairs of Georgia]

Baberovskyy, Y. (2003). Krasnyy terror.Istoryia stalinizma [Red Terror. History of Stalinism]. Moskva: Fond Pervogo prezidenta Rossii B.N. El'tsyna, 278 p. [in Russian]

Daushvyly, A., \& Natmeladze M. (2011). Noveishaia istoryia Gruzii [Recent History of Georgia]. Tbilisi, 236 p. [in Russian]

Hosudarstvennoe Kazennoe Uchrezhdenie Respubliki Adygeya "Natsyonal'nyi Arkhiv Respubliki Adygeya" [NA of the Republic of Adygea - State Institution of the Republic of Adygea "National Archives of the Republic of Adygea"]

Hosudarstvennyi arkhiv Rossiyskoi federatsyi [GARF - State Archives of the Russian Federation]

Jones, S. (1988). The Establishment of theSoviet Power in Transcaucasia: The Case of Georgia 1921 - 1928. Soviet Studies, 40(4), 616-639. [in English]

Komakhia, M. (2006). The Assyrians of Georgia: ethnic specifics should be preserved. Central Asia and the Caucasus, 3 (39), 159-164. [in English]

Kulchytskyy, S. (2014). Status tytul'nykh natsyi v psevdofederativnoy gosudarstvennoy strukture SSSR na etape sozdania sovetskogo stroya (1917-1938 gg.) [The Status of the Titular Nations in the Pseudo-federal State Structure of the USSR at the Stage of the Creation of the Soviet system (1917 1938)]. Materialy VI mezhdunarodnoy nauchnoy konferentsii (pp. 6-16). Kiev-Moskva. [in Russian] 
Lalayan, E. (1914). Aysory Vanskogo vilayeta [Aisors of the Van vilayet]. Tiflis: Typohrafiia K.P. Kozlovskogo, 39 p. [in Russian]

Martin, T. (2011). Imperyia "polozhytel'noy deyatel'nosti". Natsii y natsionalizm v SSSR, 1923 - 1939 [Empire of "Positive Action". Nations and Nationalism in the USSR, 1923 - 1939.] Moskva: Rossyiskaia politicheskaya entsiklopediya, 254 p. [in Russian]

Margulov, A. (2021) Repression as a component of national policy (Assyrians in Georgia in the 1920 s - 1930s). Introductory notes of the Taurian National University of the Name of V. I. Vernadsky. Series "Historical Sciences". 32(71), 114-120. [in Russian]

Matveev, A., \& Matveev, K. (1990). Istoryia i etnohrafiya assyryytsev (Materyaly k serii "Narody Sovetskogo Soyuza". Vypusk 1. Assyryytsy) [History and Ethnography of the Assyrians (Materials for the series "Peoples of the Soviet Union". Issue 1. Assyrians)]. Moskva, 257 p. [in Russian]

Matveev, K. (1968). Assyriyskyi vopros vo vremya i posle pervoy myrovoy voyny [Assyrian Issue during and after World War I]. Moskva: Nauka, 143 p. [in Russian]

Matveev, K. (1979). Assyriytsy i assyriyskaya problema v novoe i noveysheevremya [Assyrians and the Assyrian Problem in New and Modern Times]. Moskva, 189 p. [in Russian]

Natmeladze, M., \& Daushvyly, A. (2008). Osobennosti ustanovlenyia i ukreplenyia totalitarnogo rezhyma $v$ Gruzii $v 20-k h$ godakh XX veka [Features of the establishment and strengthening of the totalitarian regime in Georgia in the 20s of the XX century]. Tbilisi, $220 \mathrm{p}$. [in Russian]

Osypov, S. (2000). Assyryitsy Tbilisi [The Assyrians of Tbilisi]. Tbilisi, 168 p. [in Russian]

Rossyiskyi gosudarstvennyi arkhiv sotsial'no-politicheskoi istoryi [Russian State Archive of Socio-Political History - RGASPI]

Sarhyzov, L. (1979). Assyryitsy stran Blizhnego i Srednego Vostoka. Pervaya chetvert' XX v. [The Assyrians of the Near and Middle East. First quarter of the XXth century]. Erevan: Aystan, 150 p. [in Russian]

Stalyn, Y. (1946). Marksyzm y natsyonal'nyy vopros [Marxism and the National Issue]. V. 2. Moskva, 315 p. [in Russian]

Tsarakhov, B. (Comp.) (2004). Polietnitseskaya Gruziia XX veka [Multiethnic Georgia the XXth century]. Tbilisi, 135 p. [in Russian]

Tsentral'nyi istoricheskiy arkhiv Natsyonal'nogo arkhiva Gruzii [CHA of Georgia Central Historical Archive of the National Archive of Georgia]

Yacoub, J. (2015). Oublies de tous.Les assyro-chaldeens du Caucase.[Everyone Forgot. The Assyro-Chaldeens of the Caucasus]. Paris, 258 p. [in French]

Yhumen Stefan, (Sado). (2017). Martyrolog assiritsev SSSR (1920 - 1950-e gg.) [Martyrolon of the Assyrians of the USSR (1920 - 1950s)]. Sankt-Peterburh: NP-Prynt, 744 p. [in Russian]

Yunhe, M. \& Bonvech, B. (2015). Bol'shevystskyi poryadokv Gruzii [Bolshevik Order in Georgia]. V 2-kh tomakh. Moskva: AYRO-XXI, 640 p. [in Russian]

The article was received November 02, 2020. Article recommended for publishing 31/08/2021. 